\title{
IMPROVING STUDENTS' SPEAKING ABILITY BY USING SYNCHRONOUS COMMUNICATION STRATEGY
}

\author{
Ratu Yulianti Natsir \\ English Education Department, Faculty of Teacher Training and Education \\ Muhammadiyah University of Makassar \\ ratuyulianti@unismuh.ac.id
}

\begin{abstract}
The objective of the research was to find out the improvement students' speaking ability by using Synchronous Communication strategy at the second grade of SMA 1 Mappakasunggu. This research used Classroom Action Research that consisted two cycles. The research population was the second grade of SMA 1 Mappakasunggu academic year 2014/2015. The sample of this research consisted of 27 students. The researcher obtained the data by using speaking test and observation sheet. The findings of the student's speaking test in cycle I and cycle II had significantly different scores. There was a better increase of gains by students at the end of action of second cycle. The research findings indicated that the application of Synchronous Communication strategy was significant in improving the students' speaking ability of accuracy which focused on vocabulary and fluency which focused on self-confidence. It was proved by the mean score of diagnostic test was 4.5 that classified poor, the improving in cycle 1 was 6 that classified fair and cycle 2 was 7 that classified good. It means that there was the improvement of the students' speaking ability in SMAN 1 Mappakasunggu.
\end{abstract}

Keywords: Speaking Ability, Synchronous Communication Strategy

\section{INTRODUCTION}

Language as the tool of communication has the important role to understand what happens around us. People can identify and express what they feel and think by using language. Language can be expressed in the spoken or written forms which can be used in communication. And communication itself has some elements, such as the speaker, hearer, and the media. However, everything will be useless if there is no language for communication. One of the ways in communication is through speaking (Chandran, 2011:37).

Speaking is the ability that requires the process of communicative competence, pronunciation, intonation, grammar and vocabulary improving. Speaking is the most important skill, since it is one of the abilities to carry out conversation with others, give ideas and change the information with the people are able to know the situation that happen in the world. English language is not 
only taught and learned, but it is used as a habit (Florez and Cunningham, 1999:20).

Speaking refers to the gap between linguistic expertise and teaching methodology. Linguistic expertise concerns with language structure and language content. Teaching speaking is not like listening, reading, and writing. It needs habit formation because it is a real communication. The speaking needs to be practiced as often as possible. It is not like writing and reading but speaking must be practiced directly in full expression (Stevick, 1982:103).

Speaking is making use of an ordinary voice, offering words, knowing and being able to use a language expressing oneself in words, and making speech. So, speaking uses words and produces the sounds to express ideas, feeling, thought, and needs orally in an ordinary voice. In teaching English for speaking skill, the English teachers must be creative to design many communication activities in the classroom that urge and motivate students to use the language actively and productively. For this, teachers have to be aware that the students are used to inhibit in the way of how many times and how much time they speak in the classroom (Hornby in Setyowati, 2008:12).

For the beginner especially the students in junior high school, speaking exercise is difficult to try. The students always get the problem in speaking. The problems are; the first, the students always do the mistakes in grammar and pronunciation aspect. Basically, they only spoke English but they did not pay attention to the sentence structure and correct pronunciation. The second, the students are afraid of making mistake in speaking English. It indicates that the students have restrictive vocabulary. The third, the students are difficult to speak fluently since they are seldom to practice their English language (Melannie, 2012:11).

According to English teacher and based on observation in SMA Neg. 1 Mappakasunggu, the researcher consider a phenomenon among the students of SMA Neg. 1 Mappakasunggu especially at class XI that is to say, almost every one of them wishes to speak, but they find themselves difficult and even bereft to express it. It was because they do not have enough knowledge about grammar and vocabulary that actually can lead them from accuracy to fluency. This, of course, 
results in lacking confidence to speak in which they are afraid of making mistakes in speaking. In this case, the researcher focuses his attention on the speaking ability as one of the skill of language. The students are usually very eager to produce the language but they sometimes find it difficult (Chastain 1976: 334).

Beside the problems above, the model that the English teacher applies in teaching English is conventional or not effective. The students are provided a piece of paper which contain of a dialogue then they memorize and practice it in front of the class. This way makes students monotonous because they are demanded to focuses on the text. Considering to the reasons above, then the researcher focuses his attention on the speaking ability as one of the skills of language.

\section{SYNCHRONOUS COMMUNICATION STRATEGY}

Synchronous means happening, existing, or arising at precisely the same time or recurring or operating at exactly the same periods or having the same period and phase. In digital communication it refers to a transmission technique that requires a common clock signal (a timing reference) between the communicating devices in order to coordinate their transmissions. It means occurring at the same time or at the same rate or with a regular or predictable time relationship or sequence. (Desmon Keegan et al., 2005:7)

Synchronous technologies include both one-way (broadcast) technologies, such as lectures, radio, broadcast television, and Webcasts, and two-way (interactive) technologies such as face-to-face seminars, audio-conferencing, video-conferencing, web conferencing, and virtual worlds. The unifying feature of synchronous technologies is that they take place in real time; thus both teachers and students have to be communicating together at the same time (but not necessarily in the same place.). Live or synchronous e-learning is loosely defined here as "e-learning in which interactions between students and between students and the instructor take place at the same time (or in "real time")".

To improve learning through a synchronous class, it is critical to create and promote a highly collaborative environment. This task belongs to the instructor, but also is based on the learning strategy adopted before, while planning and building the agenda for the class. A low-collaborative class does not 
bring significant learning results. The more collaborative the class, the better your results will be. The audience must be part of the class, and must be called upon often by the instructor to answer questions, bring up examples or share experiences, perform some activity, etc. An efficient virtual class must be different from watching TV or going to the movies. The participants (students) must feel that they may be called upon anytime to do something, and so paying attention is critical. That's why it is also very important to work with groups of no more than 15 to 20 students per class. Large groups usually are more difficult to create a high-collaboration environment in. (Luciano Gardesani Marques Presence, 2008:18).

Students could play board games while taking synchronous learning classes for additional interaction. The researcher would display the board, and roll the dice when it's time to play. The researcher would ask a question, then display the correct answer. The students would move around the board the number of spaces indicated by the researcher when they answer the question cor-rectly,or remain on a space if they answer incorrectly. Each student should receive a paper based, or soft-copy, game board. These are easy to create in MS PowerPoint, or other drawing tools. Each student could use a coin, or other small object, to move along the board. When a student's makes it around the course, they could send a message to the researcher. Those students are the winners. Of course, the honesty system is used during this game. (Deborah Thomas, 2008: 16)

Synchronous learning comes to the rescue of students facing geographical barriers, by aiding face to face interactions with the instructor, physical constraints no bar. It has been observed that most learners find it difficult to learn without real time conversation with either the instructor or peers. This interaction, combined with an at-will access to web based courseware, augments comprehension. But, an in-depth look at the process reveals that synchronous learning has only been able to remove the physical barriers without actually adding much value to the traditional classroom based training. It supports all the learning methods that conventional learning hails, only with an added advantage of a wider student base. Though this is a pro, it is definitely not avant-garde. (Adrian LADO, 2004:6). 
According to Desmon Keegan et.al (2005:8), there are some advantages of synchronous technique:

a. Motivation - increased student commitment and motivation because a quick response is expected.

b. Tele-presence - real time interaction builds a sense of social presence and involvement.

c. Immediate feedback - encouraging quick feedback on ideas, and support consensus and decision making

d. Pacing - encouraging students to keep up-to-date and provide a discipline to learning.

e. Spontaneity - making it easy to add new ideas to the conversation, brainstorming or decision making familiarity - simulating a more traditional environment.

f. Focus on speaking.

Implementation of the synchronous communication, Synchronous used in this post is of a small group of students sitting in a room together, (seemingly) energetically talking about the issues at hand. This is an example of synchronous discussion - the students are in the same room, ostensibly discussing the same topic (the caption says they are "debating search engine liability," which sounds really interesting to me, at least). When we teach in the physical classroom, we are engaged in synchronous communication with the students. We hope that when they get into small groups they carry on the same sort of lively real-time interaction that we've modeled for them as we move around the classroom. (Anderson, 2004).

Below is a partial list of synchronous communication tools-file this under "things to think about" if not implement at some point in your teaching career. A word of advice - more like common sense, actually - don't throw a lot of different tools at your students all at once (unless it is a class specifically about tools). As with any tool, carefully consider its use before offering it as an option, and certainly before requiring its use (unless you're ready to be a role model, to play tech support, and to be a cheerleader). 
Synchronous Tools if using the "same time, different place" model of communication, some common barriers to implementation of synchronous tools are cost and bandwidth - not only cost and bandwidth on your end, as the individual teacher or the institution, but also to the students. This is especially true with conferencing systems; video/web conferencing requires equipment to deliver but also to receive. (Teng, T. \& Taveras, M, 2005).

Although the benefits of real-time video conferencing are clear-it's as near to a physical classroom environment as you could get-the software, hardware, and bandwidth necessary on both sides could be more cost-prohibitive than actually physically attending a class. Some learning management systems/elearning systems/virtual learning environments have integrated synchronous tools within the delivery platform-here I'm thinking specifically about blackboard's integrated chat and whiteboard features.

Although there are still software, hardware, and bandwidth requirements for these tools, the requirements are likely not as cost-prohibitive as those required for video conferencing. But when thinking about setting up synchronous discussion, don't discount the basic, free, "old school" group instant messaging platform, ICQ. Use synchronous means such as Telephone/Blackboard Collaborate and other web conferencing tools, instant messaging.

When communications use a synchronous method, there is a built-in timing mechanism that ensures that the clocks of the sending and receiving devices are synchronized. The most common way to do this involves embedding clocking information into the data signal. This method is called guaranteed state change synchronization.

Synchronous communications are generally more efficient than asynchronous for transferring large data packets. Most digital devices use synchronous communications; the receiving network device could synchronize its clock with the clock of the sending device when it receives the start bit. (Byron Kask .2009).

1. Synchronous communication in speaking ability

Synchronous communication in speaking ability usages time for reflection and reaction to others. It allows students the ability to work at their own 
pace and control the pace of instructional information. In addition, there are fewer time restrictions with the possibility of flexible working hours. (Bremer, 1998)

The use of the Internet and the World Wide Web allows learners to have access to information at all times. Students could also submit questions to instructors at any time of day and expect reasonably quick responses, rather than waiting until the next face-to-face meeting. Self-paced instruction will often come in a variety of synchronous formats including but not limited to:
a. Documents \& Web Pages
b. Web/Computer Based Training Modules
c. Assessments
d. Surveys
e. Simulations
f. Recorded lectures, discussions or live events

Synchronous online classes are those that require students and instructors to be online at the same time. Lectures, discussions, and presentations occur at a specific hour. All students must be online at that specific hour in order to participate.

There are benefits and drawbacks to both designs. Some students like synchronous courses because they need to feel involved, in real-time, with the class experience. It's rewarding to ask a question or offer a comment, and to receive instant feedback. For some people, real-time communication allows for more fruitful discussions.

As you're researching synchronous options, you may want to ask college enrollment advisors which elements from the following list are used at their schools.

Julie Meloni (2010) stated that Synchronous class elements are:

1. Chat (text only): Synchronous chat rooms allow multiple users to log in and interact. This is a great way to ask questions and to share resources and insights. The only drawback is that when there are a lot of people logged in, and everyone's trying to chat at the same time, the conversation could break off into tangents. The fast typists are definitely rewarded! If you're participating in a chat session, be 
sure to save the session (archive it), and review it later. You could usually save it as a .txt or .rtf file.

2. Voice (telephone or voice-over IP): Sometimes you'll be asked to dial into a toll-free number, or to log into a website where you'll speak through your built-in microphone or a headset. The purpose is to have a conference call with your instructor and/or fellow students. You may be reviewing a document or a presentation. In that case, it's extremely helpful to plan ahead of time and have all the documents you'll need at your fingertips.

3. Video conferencing: Video conferences could, in theory, require all the participants to have their webcams running. The conference administrator could then post everyone's head shot in the screen. This is not usually the case though, because to have everyone's web cam turned on and transmitting images requires a very fast connection and a lot of bandwidth. Usually, a video conference (or web conference) will involve two webcams operating -- the instructor's and that of another key person. A video conference could involve a live feed from a classroom or elsewhere. Alternatively, the conference might transmit a presentation of slides and graphics, with a question and answer session at the end.

\section{CONCEPTS OF SPEAKING}

Gronbeck, (1992 : 2) states that speaking is information by giving ideas, asking question and giving responses which have correlation with opinions, or arguments that could stimulate students to support their opinion. It is expected that through the speaking activities, the students could apply their speaking.

Speaking however particularly in English is not easy to do. Chastain, (1976 : 334) states that learning to speak is obviously more difficult than larning to understand the spoken language, because it concerns with sequential arrangement of activities that requires on the part of the teacher and the learners. So it is enough for the students to hear or to listen the speech only. Therefore, as students, they have to practice their English anywhere. A teacher should give more attention and give various activities in teaching speaking skill to increase the student ability to use the language because this case is one of the ways to improve students’ English speaking. 
Widdowson, (1985 : 57) states that speaking means of oral communication in giving impormation which involves two elements, namely the speaker is someone who gives the message and the listener is someone who receives the message. in other word, the communication involves the productive skill of listening.

Widdowson, (1985 : 58) states that an act of communication through speaking is commonly performed in face to face intraction and occurs as part of dialogue or rather from or verbal exchange. Therefore it is depends on an understanding of what else has been said in the interaction. Furthermore, Byrne, (1976: 8) states that speaking is a means of oral communication in giving ideas or impormation to others. It is the most essential way in which the speaker could express himself through the language.

Relating to the explanation above, the researcher concludes that speaking is process between speaker and listener giving information each other and both listener and speaker are active during the oral communication takes place.The act of speaking involves not only the production of the sound but also the use of gesture, the movement of the muscles of face, and indeed of the whole body. All of these non vocal of speaking as a communication activity are transmitted through the visual medium.

In speaking, there are some specific elements that have strong correlation with this skill. They are:

\section{a. Accuracy}

Based on Webster Dictionary (1996:15), accuracy is the quality of being accurate, while in oxford dictionary (1991:20) accuracy is degree of being correct. Marcel in Nursyamsi (2010) states that accuracy is a manner of people in using appropriate word and pattern of sentences. In this case, accuracy divided into three, they are pronunciation, vocabulary and grammar.

According to Harmer (1991:15), aspect of speaking could be divided as follows:

\section{1) Pronunciation}

Pronunciation is an act or result of production the sound of speech including articulation vowel formation, accent and inflection. Often with reference 
to some standard of contents or accept ability. The concept of "pronunciation" may be said to include:

a) The sound of the language

One their own the sound of language may well meaningless. If you said /t/ (the line show that this is phonetic script) a few times, e.g. tu, it will not mean very much English. Neither will be sounds $/ \mathrm{k} /, \mathrm{a} /$, or $/ \mathrm{s} /$ but if we put all these are sound together a certain order we and up the word catch and does mean something.

b) Stress

Native speaker of language unconsciously know about the stress and how it works, they know which syllables of words are stressed and they know how to use stress, to change the meaning of phrase, sentences and question.

c) Intonation

Intonation is clearly important item and component user of language recognize what meaning it has and could change the meaning of word they through using it in different ways, when we taught English language, student's need it use rhythms and stress correctly if they are to be understood.

2) Vocabulary

a) What is vocabulary

According to Webster's near world print dictionary (Webster: 1983:2946), vocabularies are list of word etc as dictionary or glossary and all of words used a language or by a person group etc.

According to Longman dictionary of contemporary English (Longman 1995:240) vocabularies are all words someone knows, learners or user the words in particularly language a list of words with explanation of their meaning, in a book for learning foreign language.

b) Types of vocabulary

Harmer in Nursyamsi (2010) distinguishes two types of vocabulary namely active vocabulary and passive vocabulary. According to him active vocabulary is that the students have learned and which they are expected to be able to use. On the other hand, passive vocabulary refers to words which the 
students will recognize when they met but will probably not be divided in to four kinds as follows:

1. Oral vocabulary consists of words actively used in speech. These are the words that come readily to one's conversation. The more often a person utters words the words the more readily it will come to his tongue.

2. Writing vocabulary is the words that come readily to one's finger vocabulary.

3. Listening vocabulary is the stock of words to which one responds with meaning and understood in speaking of other.

\section{3) Grammar}

Grammar whose subject matter is the organization of words in to variables communication, often representing many layers of structure, such as phrase sentences, and complete utterance (Ba'dulu, 2001:15). As the fame work to find sentences productively needed. The fact however shows that the learners' mastery or English structure is skill less as found out by some previous researches.

\section{b. Fluency}

Fluency refers to able to speak to write smoothly, easy reading, to an easy flow is word or able communication with base is suggested the flow an accomplished speaker and writer, it is usually a term of commendation.

According to Hornby in Nursyamsi (2010) stated that fluency is the quality or condition of being fluent. Fluency is highly complex notion relate mainly to smoothness of continuity in discourse. It includes a consideration of how sentence are connected, how sentence patterns vary in word- order and omit elements of structure and also certain aspects of the prosody of discourse.

\section{1) Self-Confidence}

Self-confidence is feeling sure that about one's ability as he states of feeling sure when people or students are able to think well. It is clear that is confidence is the ways we feel about what we are going to and also our perception how effectively we deal with other.

\section{2) Contents}

David in Zaenal (2011) states that oral communication is two ways process between speaker and listener and native the productive skill of speaking and the receptive skill understanding. It is important to remember that receptive skill not 
imply passive both in listening and reading. Language users are actively involved in the process of interrupting and negotiating meaning.

\section{RESEARCH METHODOLOGY}

This research follow the principal working of Classroom Action Research (CAR) that contains of four stages, they were: planning, implementation of action, observation and reflection. This research was holding around two cycles. They were first and second cycle and each cycle is the series of activities which have close relation. Where, the realization of the second cycle was be continue and repaired from the first cycle. There were two variables in this research, they were independent variable and dependent variable: The independent variable was synchronous communication strategy, which was the teaching aids that help the student to improve their speaking ability. The dependent variable was students speaking ability in comprehending a text.

\section{FINDINGS AND DISCUSSION}

\section{A. Findings}

\section{The Improvement of the Students' Speaking Accuracy}

The application of Synchronous Communication strategy at class XI of SMAN 1 Mappakasunggu in improving the students' speaking accuracy focused on vocabulary. Each indicator had total score and it was divided by sum of students so it results as means score in d-test, cycle I, and cycle II. So, the improvement of the students' speaking accuracy can be seen clearly in the following explanation:

Table 1.1: The Improvement of the Students' Speaking Accuracy

\begin{tabular}{|c|c|c|c|c|c|c|}
\hline \multirow{2}{*}{ Indicators } & \multicolumn{3}{|c|}{ Speaking Accuracy } & \multicolumn{3}{c|}{ Improvement (\%) } \\
\cline { 2 - 7 } & D- Test & Cycle I & Cycle II & $\begin{array}{c}\text { D-Test to } \\
\text { CI (\%) }\end{array}$ & $\begin{array}{c}\text { CI to CII } \\
(\%)\end{array}$ & $\begin{array}{l}\text { D-Test to } \\
\text { CII (\%) }\end{array}$ \\
\hline Mean Score & 4.5 & 5.5 & 7 & 22.22 & 27.27 & 5.55 \\
\hline
\end{tabular}


To see clearly the improvement of the students' speaking accuracy, look at the following chart:

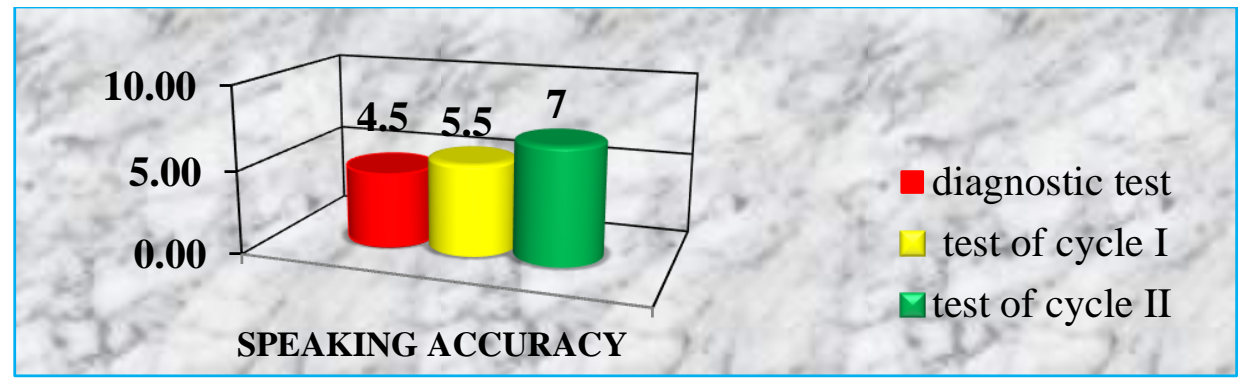

Figure 1.1: The Improvement of the Students' Speaking Accuracy

The table and chart above indicate that there was the improvement of the students' to identify accuracy from d-test to cycle I and cycle II $(4.5>5.5>7)$ in which d-test of the students' mean score in d-test was 4.5, after evaluation in cycle I, the students' mean score became 5.5 and in cycle became 7 .

The percentage of d-test until cycle 2 also improved. D-test to cycle 1 improved $22.22 \%$, cycle 1 to cycle 2 became $27.27 \%$ and d-test to cycle 2 became $55.55 \%$.

\section{The Improvement of the Students' Speaking Fluency}

The improvement of the students' speaking fluency by using Synchronous Communication strategy at class XI of SMAN 1 Mappakasunggu can be seen clearly in the following table:

Table 2.1: The Improvement of the Students' Speaking Fluency

\begin{tabular}{|c|c|c|c|c|c|c|}
\hline \multirow{2}{*}{ Indicators } & \multicolumn{3}{|c|}{ Speaking Fluency } & \multicolumn{3}{c|}{ Improvement (\%) } \\
\cline { 2 - 7 } & D- Test & Cycle I & Cycle II & $\begin{array}{c}\text { D-test to CI } \\
(\%)\end{array}$ & $\begin{array}{c}\text { CI to CII } \\
(\%)\end{array}$ & $\begin{array}{c}\text { D-Test to } \\
\text { CII (\%) }\end{array}$ \\
\hline Mean Score & 4.5 & 6 & 7 & 33.33 & 16.66 & 55.55 \\
\hline
\end{tabular}

To see clearly the improvement of the students' speaking fluency, look at the following chart: 


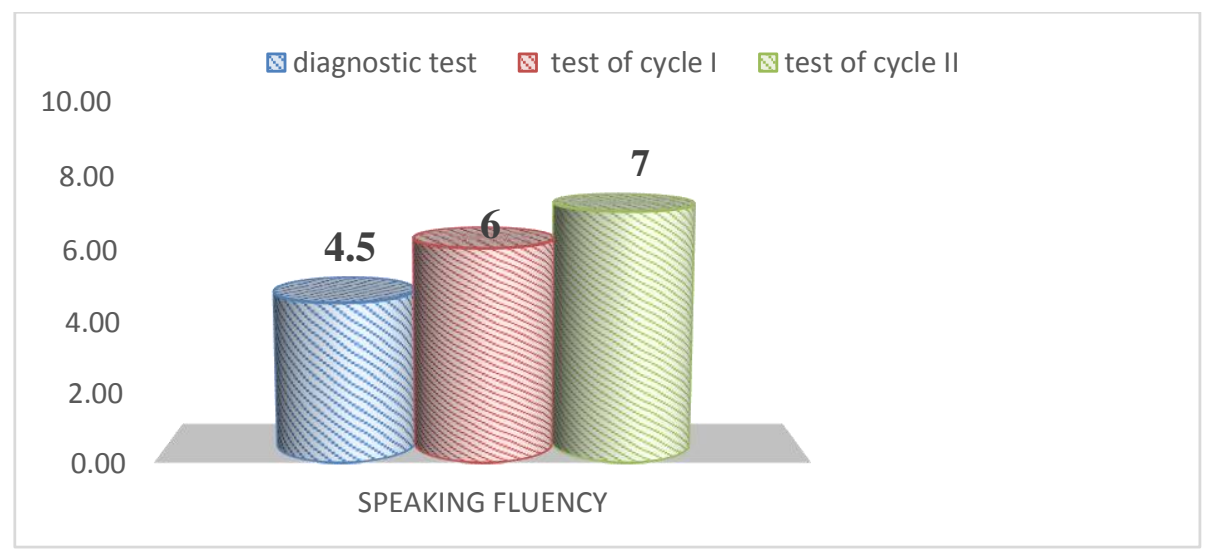

Figure 2.1: The Improvement of the Students' Speaking Fluency

The table and figure above indicate that there was the improvement of the students' to identify fluency achievement from diagnostic test to cycle I and cycle II $(4.5>6>7)$ in which d-test of the students' mean score achievement in d-test was 4.5, after evaluation in cycle I, the students' mean score became 6 and in cycle became 7 .

The percentage of d-test until cycle 2 also improved. D-test to cycle 1 improved $33.33 \%$, cycle 1 to cycle 2 became $16.66 \%$ and d-test to cycle 2 became $55.55 \%$.

\section{The Improvement of the Students' Speaking Ability}

The application of Synchronous Communication strategy in improving the students' speaking ability covered speaking accuracy and fluency at class XI of SMAN 1 Mappakasunggu can be seen clearly in the following table:

Table 3.1: The Improvement of the Students' Speaking Ability

\begin{tabular}{|c|c|c|c|c|c|c|c|c|c|}
\hline & \multicolumn{6}{|c|}{ Speaking ability } & \multicolumn{3}{|c|}{ Improvement (\%) } \\
\hline & \multicolumn{2}{|c|}{ D- Test } & \multicolumn{2}{|c|}{ Cycle I } & \multicolumn{2}{|c|}{ Cycle II } & \multirow{2}{*}{$\begin{array}{l}\text { D-test } \\
\text { to CI }\end{array}$} & \multirow[t]{2}{*}{ CI to CII } & \multirow{2}{*}{$\begin{array}{l}\text { D-test } \\
\text { to CII }\end{array}$} \\
\hline & $\mathbf{A C C}$ & FLU & $\mathbf{A C C}$ & FLU & $\overline{\mathrm{ACC}}$ & FLU & & & \\
\hline \multirow{2}{*}{$\begin{array}{l}\text { Mean } \\
\text { Score }\end{array}$} & 4.5 & 4.5 & 5.5 & 6 & 7 & 7 & \multirow[t]{2}{*}{26.66} & \multirow[t]{2}{*}{22.8} & \multirow[t]{2}{*}{55.55} \\
\hline & \multicolumn{2}{|c|}{45} & \multicolumn{2}{|c|}{ ד } & \multicolumn{2}{|c|}{7} & & & \\
\hline
\end{tabular}

To see clearly the improvement of the students' speaking ability, look at the following chart: 


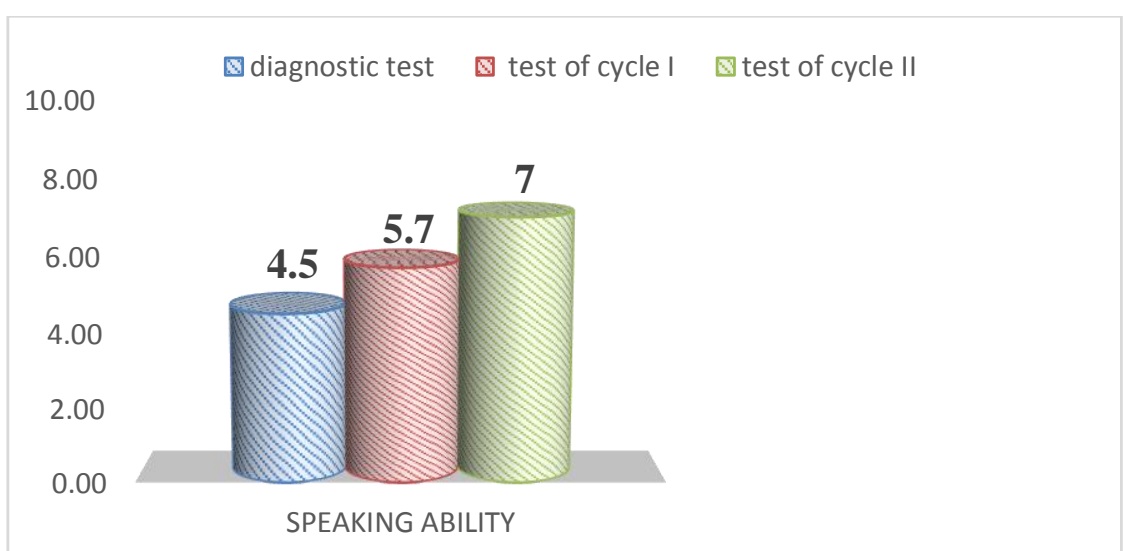

Figure 3.1: The Improvement of the Students' Speaking Ability

The table and figure above indicate that there was the improvement of the students' to identify speaking ability achievement from diagnostic test to cycle I and cycle II $(4.5>5.7>7)$ in which d-test of the students' mean score achievement in d-test was 4.5 , after evaluation in cycle I, the students' mean score became 5.7 and in cycle became 7 .

The percentage of d-test until cycle 2 also improved. D-test to cycle 1 improved $26.66 \%$, cycle 1 to cycle 2 became $22.8 \%$ and d-test to cycle 2 became $55.55 \%$.

\section{The Percentage of the Students' Accuracy}

The following table showed the percentage of student's accuracy in d-test, cycle I and II by using Synchronous Communication strategy.

Table 4.1: The Percentage of the Students' Speaking Accuracy

\begin{tabular}{|c|c|c|c|c|c|c|c|c|}
\hline \multirow[t]{3}{*}{ No } & \multirow[t]{3}{*}{ Classification } & \multirow[t]{3}{*}{ Range } & \multicolumn{2}{|c|}{ Non SC } & \multicolumn{4}{|c|}{ The Application of SC } \\
\hline & & & \multicolumn{2}{|c|}{ D-test } & \multicolumn{2}{|c|}{ Cycle I } & \multicolumn{2}{|c|}{ Cycle II } \\
\hline & & & Freq & $\%$ & Freq & $\%$ & Freq & $\%$ \\
\hline 1 & Excellent & $9.6-10$ & 0 & 0 & 0 & 0 & 0 & 0 \\
\hline 2 & Very good & $8.6-9.5$ & 0 & 0 & 0 & 0 & 0 & 0 \\
\hline 3 & Good & $7.6-8.5$ & 0 & 0 & 3 & 11 & 7 & 26 \\
\hline 4 & Fairly good & $6.6-7.5$ & 4 & 15 & 6 & 22 & 13 & 48 \\
\hline 5 & Fair & $5.6-6.5$ & 0 & 0 & 0 & 0 & 0 & 0 \\
\hline 6 & Poor & $4.6-5.5$ & 11 & 41 & 15 & 55 & 7 & 26 \\
\hline 7 & Very poor & $0-4.5$ & 12 & 44 & 3 & 11 & 0 & 0 \\
\hline & Total & & 27 & 100 & 27 & 100 & 27 & 100 \\
\hline
\end{tabular}

Vol. 5 No. 2 November 2016 
The table above shows the percentage of the students' accuracy achievement in d-test indicates that 4 students (15\%) got fairly good, 11 students (41\%) got poor, 12 students $(44 \%)$ got very poor, and none of students for the other classification. After taking action in cycle I by using Synchronous Communication strategy, the percentage of the students' accuracy achievement improved where 3 students (11\%) got good, 6 students (22\%) got fairly good, 15 students (55\%) got poor and 3 students (11\%) got very poor. In cycle II, the percentage of the students' achievement in accuracy was higher than cycle I where 7 students (26\%) got good, 13 students (48\%) got fairly good and 7 students $(26 \%)$ got poor.

To know the percentage of the students' improvement in speaking accuracy, look at the chart, as follows:

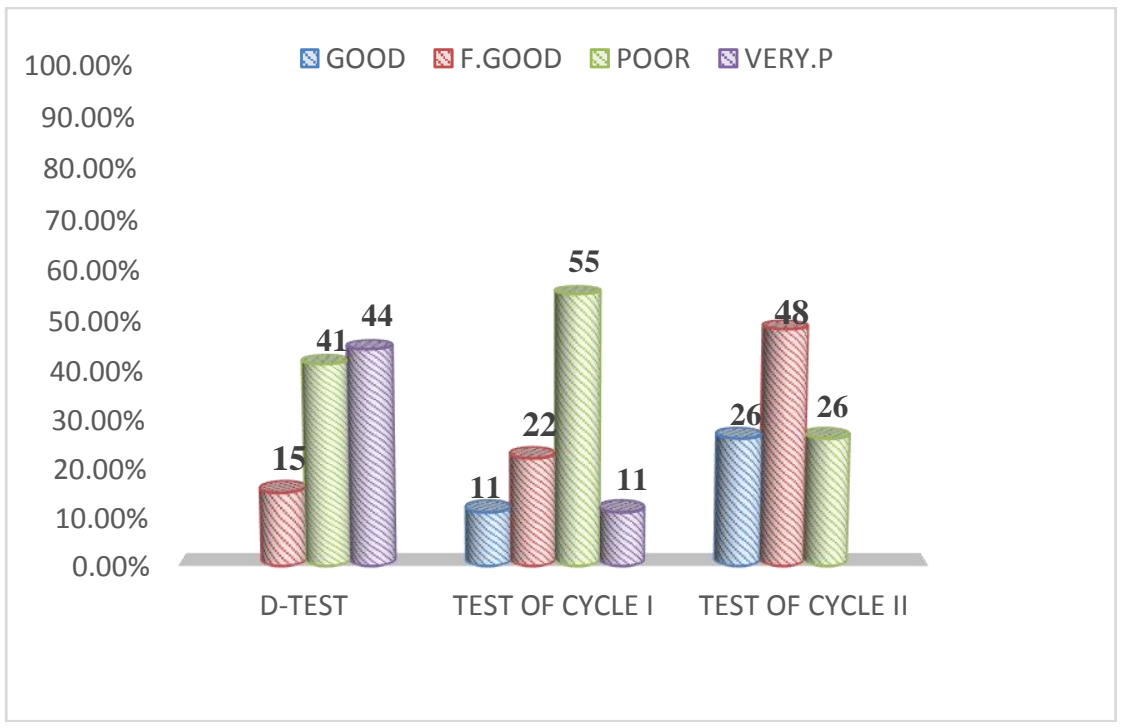

\section{Figure 4.1: The Percentage of the Students' Speaking Accuracy}

The chart above shows that the result of the students' speaking accuracy focused on vocabulary. Synchronous Communication strategy in cycle I and cycle II, the result of students' Synchronous Communication strategy achievement improved significantly.

The result of students' accuracy in cycle II was higher than d-test and cycle I (Cycle II > Cycle I > d-test) where the students' accuracy achievement in cycle II was $26 \%$ as good, $48 \%$ as fairly good and $26 \%$ as poor while in cycle I was lower than cycle II where the students' accuracy achievement in cycle I was $11 \%$ as good, $22 \%$ as fairly good, $55 \%$ as poor, $11 \%$ as very poor and non of for 
the other classification. The result of d-test was the lowest than the other where the students' accuracy achievement was (15\%) as fairly good, 41\%) as poor and $(44 \%)$ as very poor. The result above proved that the use of Synchronous Communication strategy was able to improve the students' accuracy in speaking.

\section{The Percentage of The Students' Speaking Fluency}

The application of Synchronous Communication strategy in improving the students' speaking fluency can be seen the difference clearly by considering the result of the students' d-test and result of the students' test in cycle I and cycle II.

Table 5.1: The Percentage of the Students' Fluency

\begin{tabular}{|c|c|c|c|c|c|c|c|c|}
\hline \multirow{2}{*}{ No } & Classification & \multirow{2}{*}{ Score } & \multicolumn{2}{|c|}{ Non SC } & \multicolumn{3}{c|}{ The Application of SC } \\
\cline { 4 - 8 } & & & \multicolumn{2}{|c|}{ D-Test } & \multicolumn{2}{c|}{ Cycle I } & \multicolumn{2}{c|}{ Cycle II } \\
\cline { 4 - 8 } & & Freq & $\%$ & Freq & $\%$ & Freq & $\%$ \\
\hline 1 & Excellent & $9.6-10$ & 0 & 0 & 0 & 0 & 0 & 0 \\
\hline 2 & Very good & $8.6-9.5$ & 0 & 0 & 0 & 0 & 0 & 0 \\
\hline 3 & Good & $7.6-8.5$ & 0 & 0 & 2 & 7 & 8 & 30 \\
\hline 4 & Fairly good & $6.6-7.5$ & 2 & 7 & 12 & 44 & 13 & 48 \\
\hline 5 & Fair & $5.6-6.5$ & 0 & 0 & 0 & 0 & 0 & 0 \\
\hline 6 & Poor & $4.6-5.5$ & 15 & 55 & 13 & 48 & 6 & 22 \\
\hline 7 & Very Poor & $0-4.5$ & 10 & 37 & 0 & 0 & 0 & 0 \\
\hline \multicolumn{2}{|c|}{ Total } & & 27 & 100 & 27 & 100 & 27 & 100 \\
\hline
\end{tabular}

The table above shows that the percentage of the students' fluency in speaking d-test indicated that 2 students (7\%) got fairly good, 15 students (55\%) got poor and 10 students (37\%) got very poor.

After taking an action in cycle I by using Synchronous Communication strategy, the percentage of the students' fluency was 2 students (7\%) got good, 12 students (44\%) got fairly good and 13 students (48\%) got poor.

In cycle II, the percentage of the students' fluency in speaking was 8 students (30\%) got good, 13 students (48\%) got fairly good and 6 students (22\%) got poor. The result above also proved that the use of Synchronous Communication strategy was able to improve the students' speaking fluency where result of Cycle II was higher than cycle I and d-test (C II >C I, C I > d-test).

To know the percentage of the students' improvement in fluency clearly, look at the chart, as follows: 


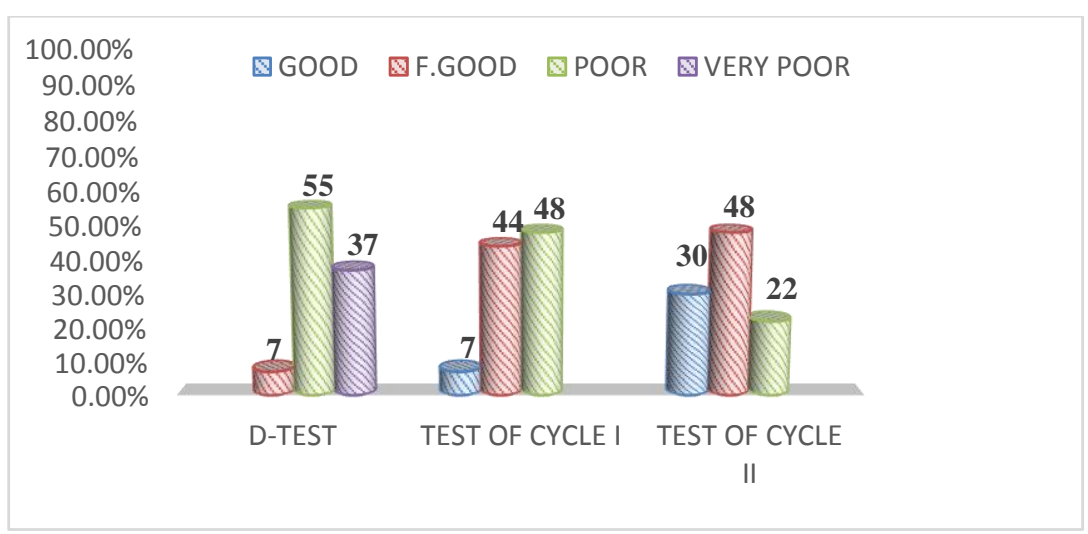

Figure 5.1: The Percentage of the Students' Speaking Fluency

The chart above shows that the result of the students' by using Synchronous Communication strategy in cycle I and cycle II, the result of students' fluency achievement improved significantly where Cycle II was higher than d-test and cycle I. The students' fluency achievement in cycle II was $30 \%$ as good, $48 \%$ as fairly good, $22 \%$ as poor while in cycle I was lower than cycle II where the students' fluency achievement in cycle I was $7 \%$ as good, $44 \%$ as fairly good and $48 \%$ as poor. The d-test was the lowest where the students' fluency achievement was $7 \%$ as fairly good, $55 \%$ poor, and $37 \%$ as very poor.

The result above proved that the use of Synchronous Communication strategy was able to improve the students' Fluency in speaking.

\section{The Improvement of the Students' Activeness}

The result of observation of the students' activeness in teaching and learning process by using Synchronous Communication strategy in improving the students' speaking ability at the eleventh class student of SMAN 1 Mappakasunggu. Which was conducted in 2 cycles during 8 meetings was taken by the observer through observation sheet. It can be seen clearly through the following table: 
Table 6.1: The Improvement of the Students' Activeness

\begin{tabular}{|c|c|c|c|c|c|}
\hline \multirow{2}{*}{ Cycle } & \multicolumn{4}{|c|}{ Meetings } & \multirow{2}{*}{$\begin{array}{c}\text { Average } \\
\text { Score }\end{array}$} \\
\cline { 2 - 5 } & I & II & III & IV & \\
\hline I & $59 \%$ & $65 \%$ & $62 \%$ & $70 \%$ & $64 \%$ \\
\hline II & $66 \%$ & $65 \%$ & $68 \%$ & $71 \%$ & $67.5 \%$ \\
\hline
\end{tabular}

The result above was formulated based on the technique of data analysis and the students' scores that are collected through observation sheet. From the table above showed that in cycle I the students' activeness in each meeting improved. It could be seen clearly in table that the students' activeness in cycle 2 $(67.5 \%)$ was higher than cycle $1(64 \%)$.

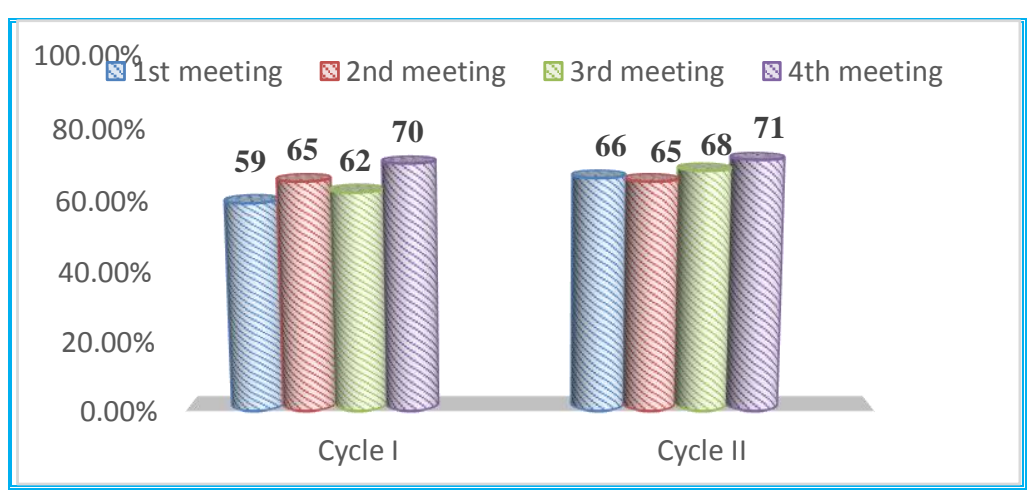

Figure 6.1: The Improvement of the Students' Activeness

The chart above shows that there was improvement of students' activeness in teaching and learning process where in cycle I the students' presence and activeness in each meeting improved. It could be seen clearly in the chart that in cycle $267.5 \%$ was higher than cycle $164 \%$.

\section{B. Discussion}

1. The Improvement of the Students' Speaking Accuracy Focused on Vocabulary

a. Vocabulary

The application of Synchronous Communication Strategy in improving the students' speaking accuracy in terms of vocabulary can be seen the difference by considering the result of the students' diagnostic test and the students' 
improvement after taking action in cycle I and cycle II through the application of Synchronouse Communication strategy in teaching learning process.

The improvement of the students' to identify vocabulary from d-test to cycle I and cycle II $(4.5>5.5>7)$ in which d-test of the students' mean score in d-test was 4.5, after evaluation in cycle I, the students' mean score became 5.5 and in cycle became 7 .

The percentage of d-test until cycle 2 also improved. D-test to cycle 1 improved $22.22 \%$, cycle 1 to cycle 2 became $27.27 \%$ and d-test to cycle 2 became $55.55 \%$.

The percentage of the students' accuracy achievement in d-test indicates that 4 students (15\%) got fairly good, 11 students (41\%) got poor, 12 students (44\%) got very poor, and none of students for the other classification. After taking action in cycle I by using Synchronous Communication strategy, the percentage of the students' accuracy achievement improved where 3 students (11\%) got good, 6 students (22\%) got fairly good, 15 students (55\%) got poor and 3 students (11\%) got very poor. In cycle II, the percentage of the students' achievement in accuracy was higher than cycle I where 7 students (26\%) got good, 13 students (48\%) got fairly good and 7 students (26\%) got poor.

From the explanation above the researcher analyzed that the use of Synchronous Communication strategy can improve students' speaking vocabulary where the students mean score in cycle I and cycle II was higher than d-test.

\section{The Improvement of the Students' Speaking Fluency focused on Self-}

\section{Confidence}

The application of Synchronous Communication strategy in improving the students' speaking fluency focused on self-confidence can be seen the difference by considering the result of the students' D-test and the students' improvement after getting action in each cycles.

The improvement of the students' to identify fluency achievement from diagnostic test to cycle I and cycle II $(4.5>6>7)$ in which d-test of the students' mean score achievement in d-test was 4.5 , after evaluation in cycle I, the students' mean score became 6 and in cycle became 7 . 
The percentage of d-test until cycle 2 also improved. D-test to cycle 1 improved $33.33 \%$, cycle 1 to cycle 2 became $16.66 \%$ and d-test to cycle 2 became $55.55 \%$.

The percentage of the students' fluency in speaking d-test indicated that 2 students (7\%) got fairly good, 15 students (55\%) got poor and 10 students (37\%) got very poor.

After taking an action in cycle I by using Synchronous Communication strategy, the percentage of the students' fluency was 2 students (7\%) got good, 12 students (44\%) got fairly good and 13 students (48\%) got poor.

In cycle II, the percentage of the students' fluency in speaking was 8 students (30\%) got good, 13 students (48\%) got fairly good and 6 students (22\%) got poor. The result above also proved that the use of Synchronous Communication strategy was able to improve the students' speaking fluency where result of Cycle II was higher than cycle I and d-test (C II $>C$ I, C I>d-test).

From the explanation above the researcher analyzed that the use of Synchronous Communication strategy could improve students' speaking selfconfidence where the students mean score in cycle I and cycle II was higher than d-test.

The observation result of students' activeness in teaching and learning process improved significantly by using the application of Synchronous Communication strategy in improving the students' speaking ability.

\section{The Improvement of the Students' Speaking Ability}

There was the improvement of the students' to identify speaking ability achievement from diagnostic test to cycle I and cycle II $(4.5>5.7>7)$ in which $\mathrm{d}$ test of the students' mean score achievement in d-test was 4.5, after evaluation in cycle I, the students' mean score became 5.7 and in cycle became 7 .

The percentage of d-test until cycle 2 also improved. D-test to cycle 1 improved $26.66 \%$, cycle 1 to cycle 2 became $22.8 \%$ and d-test to cycle 2 became $55.55 \%$. 


\section{CONCLUSION}

Based on the research findings and discussion in the previous chapter, the researcher draws conclusion that the application of Synchronous Communication strategy could significantly improve the students' speaking ability in terms of accuracy focused on vocabulary and fluency focused on self-confidence Synchronous Communication strategy at class XI of SMAN 1 Mappakasunggu. It can be seen from comparing the mean score of the students' speaking ability in diagnostic test was 4.5. It was categorized as poor classification. While the mean score of the students' speaking test in cycle I became 5.7. It was higher than the mean score of the students' diagnostic test. But the result was not significant from the result which was expected according to the background namely 7.0. Cycle II and the mean score of the students' speaking test was 7. It indicates the significant score from the result expected in the background namely 7.0. The result above was acquired from the students' speaking ability in terms of speaking accuracy and speaking fluency.

\section{BIBLIOGRAPHY}

Bill Brandon. 2008144 Tips on Synchronous e-Learning Strategy + Research. www.elearningguild.com.

Ellis, R. (1996). The Study of Second Language Acquisition. Oxford: Oxford University Press.

Fotos, S. 1998. Shifting the Focus from Forms to Form in the ELT Classroom. ELT Journal, 52(4), 605-628.

Gay, L.R, 1981. Educational Research; Competencies for Analysis and Applications. Columbus: Charcks, E. Merril Publishing Co.

Hamka.2011. Improving Students' Speaking Proficiency Through Case Presentation Method At Class XI Ipa 1 Of Sma Negeri 9 Makassar (A Classroom Action Research) Retrieved from August 2012. FKIP University of Muhammadiyah Makassar.

Harmer, J., 1991. The Practice of English Language Teaching. London and New York Longman Group 
Hedge, T. (2000). Teaching and Learning in the Language Classroom. Oxford University Press.

Herminingsih,D.I,2009. Forms-Focused and Meaning-Focused Istruction Model to Promote Speaking Ability in English Class. Dinamika Volume 9, (7778).Retrievedfromhttp://www.googlr.co.id/isjd.pdii.lipi.go.id/admin/jurnal/ 91097686.pdf [0n 21 July 2012 ]

Hornby. A.S. 1974. Oxford Advanced Learner's Dictionary of Current English. Third Edition. New York: Oxford University Press.

Krashen, S. D., \& Terrell, T. D. 1998. The natural approach: Language acquisition in the classroom. Prentice Hall International.

Larsen - Freeman, D. 1987. Techniques and Principles in Language

Teaching. Oxford: Oxford University.

Larsen-Freeman, D. 2001. Techniques and principles in language teaching $\left(^{\text {nd }}\right.$ Ed.). Oxford: Oxford University Press.

Lightbown, P., \& Spada, N. 1990. Focus-on-form and corrective feedback in communicative language teaching: Effects on second language learning. Studies in Second Language Acquisition, 12, 429-448.

Lightbown, P., \& Spada, N. 1999. How languages are learned. Oxford: Oxford University Press.

Long, H. L. 1983 Does second language instruction make a difference? A review of Research. TESOL Quarterly 17: (3) 359-382

Long, M. 1991. Focus on form: A design feature in language teaching methodology.

Long, M., \& Robinson, P. 1998. Focus on form: Theory, research, and practice. In C. Doughty and J. Williams (Eds.). Focus on form in classroom second language acquisition. Cambridge: Cambridge University Press.

Long, M.H. 1981 Input, Interaction and Second Language Acquisition. In Winitz,

S. (Ed.) Native Language and Foreign Language Acquisition. New York. New York Academy of Science.

Macías Diego Fernando. 2011. Towards The Use of Focus On Form Instruction In Foreign Language Learning And Teaching In Colombia. 
Íkala vol.16 no.29 Medellín.

Retrieved

From

http://aprendeenlinea.udea.edu.com on 22 July 2012

Nishimura, K. 2000. Effective ways of communicative instruction in the Japanese EFL classroom: Balancing fluency and accuracy. Retrieved From http://www.eric.ed.gov/ERICWebPortal/search/detailmini on 21 July 2012

Nunan, D. (1998). Teaching Grammar in Context. ELT journal, 52, 101-109.

Office of information technology OIT. 2010 When, Why, and How to Use Synchronous vs. Asynchronous Communication.

Seedhouse, P. 1997. Combing form and meaning. ELT Journal, 51(4), 336344.Retrieved from http://eltj.oxfordjournals.org/content/51/4/336.short on 23 July 2012.

Sixia Gao. 2009. Focus on Form in College English Teaching. English language teaching volume 2 (46-48). Retrieved from www.ccsenet.org/journal.Html

Tom Worthington.2013 Synchronizing Asynchronous Learning Combining Synchronous and Asynchronous Techniques Australian National University Canberra, Australia

Wallace, C. 1988. Action Research for Teacher. Cambridge: Cambridge University Press.

Widdowson, H. G. 1979. Teaching language as a communication. Oxford: Oxford University press. 